\title{
Variability and trends of rainfall extreme events in north east highlands of Ethiopia
}

\begin{abstract}
This study was conducted in south Wollo to investigate the spatio-temporal variability of nine extreme rainfall indices and their trends. The daily rainfall was obtained from six meteorological stations in the period (1984-2014). Sen's slope estimator and Mann-Kendall's test were used to determine the magnitude and trends of changes, respectively. The results showed complex patterns of rainfall. Rainfall significantly $(\mathrm{P}<0.05)$ increased in summer in some of the stations (Dessie, Haik and Mekaneselam) and showed declining tendency in spring at all studied stations. The mean annual consecutive dry day significantly decreased at Dessie, Haik and Wereilu whereas consecutive wet days significantly increased at Ambamariam, Dessie and Mekaneselam. Trends in mean annual number of wet days, total wet day rainfall and simple daily rainfall intensity index did not show significant changes. The study revealed that rainfall pattern of the studied stations was changed into mono modal (summer) and the inter-annual and seasonal rainfall variability was high. These results highlight the need for planning effective adaptation strategies.
\end{abstract}

Keywords: climate, variability, warming, trends, extremes, indices
Volume 2 Issue 5 - 2018

\author{
Yimer Mohammed,' Fantaw Yimer,' Menfese \\ Tadesse,' Kindie Tesfaye ${ }^{2}$ \\ 'Hawassa University, Ethiopia \\ ${ }^{2}$ International Maize and Wheat Improvement Center \\ (CIMMYT), Addis Ababa, Ethiopia
}

Correspondence: Yimer Mohammed, Hawassa University,
Ethiopia,Tel +251 911186477 ,

Email yamermoh2013@gmail.com

Received: March 08, 2018 | Published: October 10, 2018

\section{Introduction}

There is no doubt that the climate has changed and is continuing to change. Climate change is inevitably resulting in changes in climate variability and in the frequency, intensity, spatial extent, duration, and timing of extreme weather events. ${ }^{1}$ It is widely expected that as the planet warms, regardless of future emissions, climate and weather variability will increase. Increasing trends in frequencies of heat stress, drought and flooding are projected to be continued for the rest of this century, and these are expected to have many adverse effects over and above impacts due to changes in mean variables alone..$^{1,2}$ Each of the last three decades has been successively warmer at the Earth's surface than any preceding decades since 1850 . The period from 1983 to 2012 was the warmest 30-year period of the last 800 years in the Northern Hemisphere. ${ }^{3}$ It is very likely that the number of cold days and nights has decreased and the number of warm days and nights has increased on the global scale., ${ }^{3,4}$ The rainfall also increased by $0.5-1.0 \%$ per decade in mid- and high latitude areas of Northern Hemisphere. However, the trend in the subtropics has weakened over the recent decades. ${ }^{5}$ Associated with global warming, there are strong indications that rainfall changes are already taking place on both global and regional scales. ${ }^{6,7}$ Extreme rainfall changes over eastern Africa such as droughts and heavy rainfall show high degree of temporal and spatial variability dominated by a variety of physical processes. ${ }^{8-11}$ Indicate that over the last 3 decades rainfall has decreased over eastern Africa between March and May/June. The suggested physical link to the decrease in rainfall is rapid warming of the Indian Ocean, which causes an increase in convection and rainfall over the tropical Indian Ocean and thus contributes to increased subsidence over eastern Africa and a decrease in rainfall during March to May/June. Similarly, ${ }^{12}$ showed a decline in the March-May seasonal rainfall over eastern Africa.

Various studies on rainfall patterns of Ethiopia have been carried out with a range of spatial (e.g. national, regional) and temporal (e.g. annual, seasonal, monthly) scales. Unlike temperature, studies on rainfall did not show any consistent pattern or trends. ${ }^{13}$ also found that summer rainfall in central highlands of Ethiopia declined in the second half of the 20th century, while ${ }^{14,15}$ did not find such a trend over central, northern, and northwestern Ethiopia. Instead, they found a decline of annual and summer rainfall in eastern, southern, and southwestern Ethiopia since $1982 .{ }^{16}$ confirmed the findings of ${ }^{14}$ i.e decline of annual rainfall in southwestern and eastern Ethiopia, but argued that while rainfall has been declining in the Northeast since 1996, summer rain has been consistent (i.e. no trends) for the entire nation since the $1960 \mathrm{~s}$. In contrast to,${ }^{16-18}$ confirmed the absence of recent trends in rainfall over the northeastern Ethiopian highlands. The findings of ${ }^{19,20}$ also showed the absence of consistent emergent patterns or trends in daily rainfall characteristics in Amhara region and south western part of Ethiopia respectively. Contrary to Conway, 5,17 found non significant increasing trend in the upper Blue Nile river basin. On the other hand, ${ }^{21}$ reported that rainfall shows a weak rising trend in the arid lowlands of southeastern Ethiopia and downward trend over the western highlands and Sudan border. The opposite trends were reported by ${ }^{22}$ for the period $1971-2010 .{ }^{23}$ also reported that spring and summer rainfall decreased by $15-20$ percent across parts of southern, southwestern, and southeastern Ethiopia between the mid-1970s and late 2000s.

Various studies on the variability and trend of extreme rainfall events which were conducted in different parts of Ethiopia reported complex patterns for the daily indices examined. For example, ${ }^{24}$ reported declining trends in frequency of heavy rains. In contrary, ${ }^{20}$ found absence of systematic trends for the number of wet and dry day-related rainfall indices in Southwestern part of Ethiopia for the period 1980-2007..$^{14}$ found non significant trends in the central and northern parts of the country and significant decreasing trends in the eastern part for the summer season over the period 1962-2002. For the same period, ${ }^{25}$ found statistically significant declining trends for the wet day intensity and maximum consecutive 5-day rain over the southwestern, southern and eastern parts during the summer and spring seasons. ${ }^{26}$ identified a complex pattern of daily rainfall trends in the southwestern part of Ethiopia over the period 1978-2007. ${ }^{27}$ 
found increasing trend in frequency of dry extremes and ${ }^{28}$ identified increasing trend in the number of warm days and nights. Similarly, found no significant trends in rainy days, rainfall intensity and dryspell length in south Wollo for the spring and summer seasons over the period 1963-2003. ${ }^{29,30}$ also noted late onset and early cessation of rainfall in West Amhara over the period 1979-2008 and Tigray for the period 1980-2009 respectively. Many of the contradictions in previous findings on rainfall trends and climate extremes in Ethiopia may be explained by the arbitrary division of the study area, the study period chosen as well as the quality of the available data. . $^{4,19,20,24}$

Research on the variability and trends of the regional and localscale rainfall amounts and extreme events is very important for the assessment of climate change impacts. Accurate quantification of the variability, trends and frequency of extreme events, not captured by small changes in long term mean, have a paramount importance in designing appropriate adaptation strategies. The objective of this paper was, therefore, to assess the variability and trends in extreme rainfall events in different parts of south Wollo, Ethiopia. Strictly speaking climate and weather variability in the study area was poorly monitored. These days it is not mainly the mean value of climate elements bringing a noticeable impact rather the occurrence and frequency of extreme events. Since information on rainfall characteristics in dry land areas is critical for agricultural planning, this study gives attention for a detailed analysis of trend and variability of rainfall extreme events. Moreover, the presence of complex patterns of daily rainfall trends in Ethiopia as shown by various studies implies that further localscale detail investigations into variability and trend of extreme rainfall and temperature events are necessary to understand and characterize local-scale manifestations of climate change and accordingly design local-specific adaptation interventions. For example, ${ }^{7}$ in their study of "Variability of rainfall and its current trend in Amhara region, Ethiopia" recommended that increasing the number of study stations for improving precision and reliability of the application of the findings for practical use is central.

This study therefore contributes valuable information on variability and trend of extreme rainfall events which has practical implications for an effective management of water resources and climate risk management. Moreover, since over three-fourth of the study area is found in the upper Blue Nile river basin, where the Grand Renaissance Dam of Ethiopia is found, dealing with extreme daily rainfall events also has an important implications to understand rates of sedimentation into renaissance dam and landscape management. Further, the study adds to the existing scarce knowledge on local-scale rainfall variability and trends in climate extremes in Ethiopia

\section{Materials and methods \\ Description of the study area}

South Wollo zone is located in North east part of Ethiopia and in geographic terms it lies with in $10^{\circ} 12^{\prime} \mathrm{N}$, and $11^{\circ} 40^{\prime} \mathrm{N}$ latitude and $38^{\circ} 30^{\prime} \mathrm{E}$ and $40^{\circ} 05^{\prime} \mathrm{E}$ longitude. Its zonal capital, Dessie, is found $400 \mathrm{kms}$ North of Addis Ababa. It is one of the drought-prone and aid-dependent areas in Amhara regional state. ${ }^{19}$ It is found in Amhara National regional state in the federal political arrangement of Ethiopia. It covers a total area of $17,053.45 \mathrm{~km}^{2}$ and divided into eighteen rural and two urban woredas. South Wollo is characterized by diverse topographic features in which high mountainous and deeply incised canyons and gorges, valleys and plateaus with steep slopes dominate its most parts. ${ }^{31}$ The elevation ranged from the dry plains at $1000 \mathrm{~m}$ altitude in the east to the high peaks above $3500 \mathrm{~m}$ altitude in the west. However high-land areas ranging between $1500 \mathrm{~m}$ and 3500 $\mathrm{m}$ altitude are the dominating feature of South Wollo. ${ }^{8}$ Because of the diverse topography, the study area experiences different climatic conditions that range from hot and arid lowlands in the eastern part to cold and humid highlands in the western part.

The mean annual temperature varies from less than $5^{\circ} \mathrm{C}$ in the western highlands to $22^{\circ} \mathrm{C}$ in the eastern lowlands. The annual rainfall varies between less than $1000 \mathrm{~mm}$ in the western part to more than $1200 \mathrm{~mm}$ in the eastern part. Bimodal rainfall pattern (small spring and longer summer) characterizes the study area which leads to two harvest periods. In the spring season, rain falls during March to May and in summer season it falls from July to September. The spring season is noticeable for mid to high latitude areas whereas the mid land to lowland areas mainly depends on the summer rain. Crop production is rainfed except a few pocket areas where small-scale irrigation is practiced. The soil types found in the study areas are predominantly volcanic in origin and belong to the Trappean series. Despite no detailed soil surveys have been carried out and not scientifically quantified, many years of continuous cultivation, limited application of nutrients and the removal of all crop residues seem to have depleted the fertility status of the soil. Soil erosion is a critical problem in Amhara region in which 58\% of the soil eroded in the country is from this region. ${ }^{32}$ The study area is highly degraded and deforested in terms of indigenous trees but does have substantial eucalyptus plantations. Alpine species unique to extreme highland areas are found in western highland parts of the study area. Local people in the area are engaged in subsistence agriculture for their livelihood. Unlike other areas of East Africa where highlands generally are the most food secure parts of a country, the opposite often is the case in Ethiopia. In fact, the crowded, steep-sloped highlands above 2,000 metres a.s.l., including large parts of South Wollo, are among the country's most famineprone areas shows in Figure $1 .^{33}$

\section{Methodology}

Data set: Observed daily rainfall data were obtained from the National Meteorological Agency of Ethiopia (NMA). At the beginning, historical records of daily rainfall were examined in all meteorological stations found in South Wollo. Unfortunately, most of the stations had records only over a short period or had many discontinuities. Stations for final study were selected based on representativeness within a given agro-ecology and length of record period. In order to cover the study area relatively long rainfall records (1984-2014) were obtained with a reasonably good geographic distribution from six stations (Table 1).

Data quality control: In climate data analysis, the big problem is missing of the observed daily data. However, in many sites in the SubSaharan Africa there are no consistent data records, data may exist for short periods, with long periods of missing data.$^{34}$ By considering the maximum flexible thresholds of $10 \%$ missing values adopted by, ${ }^{35}$ six stations Ambamariam, Combolcha, Dessie, Haik, Mekaneselam and Wereilu were taken for analysis of rainfall extremes. We also plotted the data of 6 stations against time in days of the year format and subjected to visual examination for the presence of outliers and missing values as well as typing errors such as negative rainfall values,. There are various techniques currently used for filling the missed data. For this study, inverse distance method was used to estimate the missed rainfall data. 


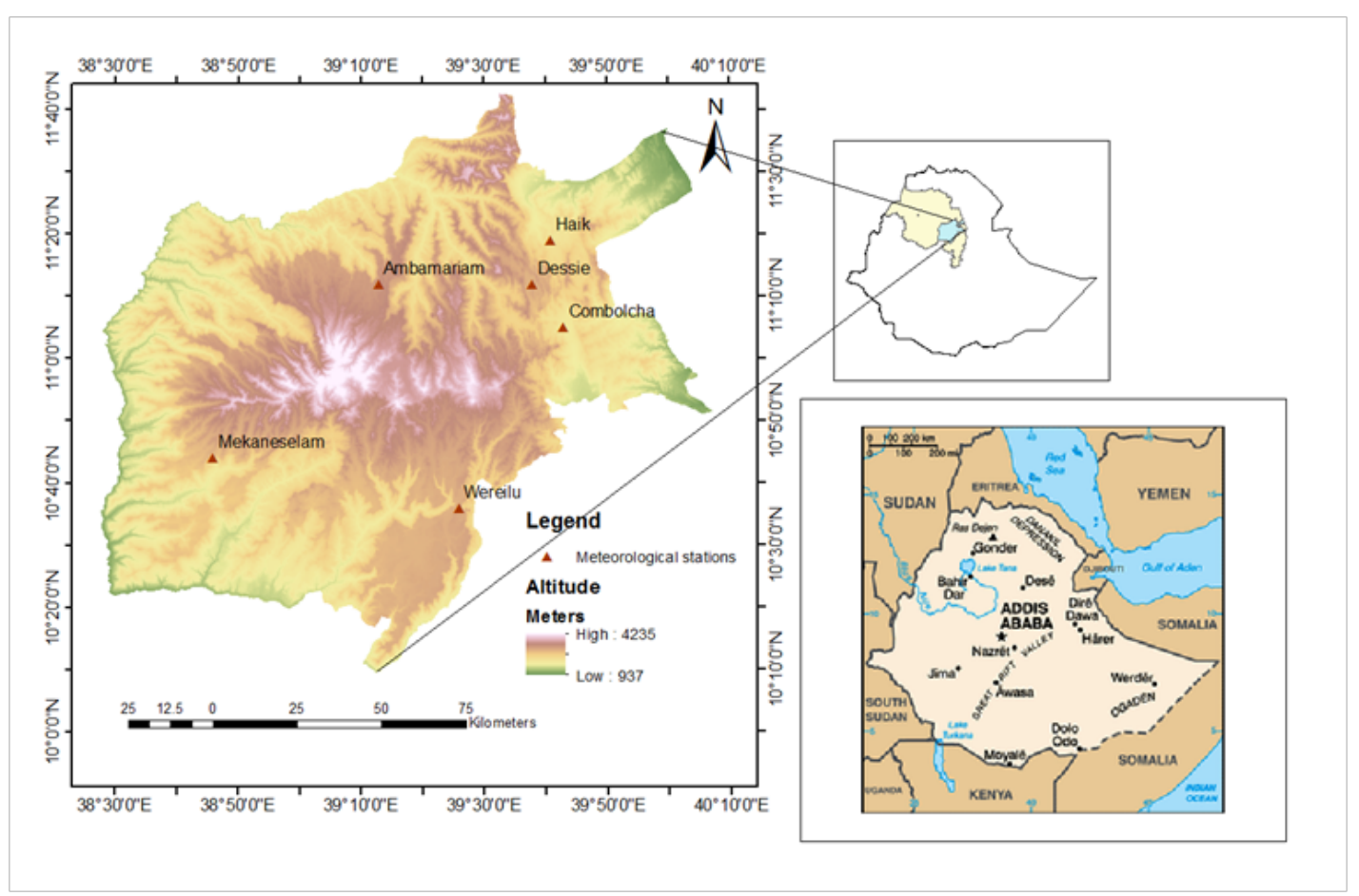

Figure I Location map of south Wollo, meteorological stations used in this study.

Table I Geographic information of the selected weather stations used for this study

\begin{tabular}{|c|c|c|c|c|c|}
\hline Station & Latitude (N) & Longitude (E) & Elevation $(\mathrm{m})$ & Years of observation & $\begin{array}{l}\text { No. of years with } \\
\text { missing values }\end{array}$ \\
\hline Ambamariam & $11 \circ 12^{\prime}$ & $39^{\circ} 13^{\prime}$ & 2990 & $1984-20 \mid 4$ & 1 \\
\hline Combolcha & $11^{\circ} 05^{\prime}$ & $39^{\circ} 43^{\prime}$ & 1857 & $1984-20 \mid 4$ & - \\
\hline Dessie & $11{ }^{\circ} 12^{\prime}$ & $39 \circ 38^{\prime}$ & 2553 & $1984-20 \mid 4$ & I \\
\hline Haik & $11019^{\prime}$ & $39 \circ 4 I^{\prime}$ & 1985 & $1984-20 \mid 4$ & I \\
\hline Mekaneselam & $10^{\circ} 44^{\prime}$ & $38^{\circ} 46^{\prime}$ & 2605 & $1984-20 \mid 4$ & I \\
\hline Wereilu & $10^{\circ} 36^{\prime}$ & $39^{\circ} 26^{\prime}$ & 2690 & $1984-20 \mid 4$ & I \\
\hline
\end{tabular}

Defining extreme events: Following the ${ }^{36}$ guidelines, nine daily rainfall indices were defined and used in this study (Table 2). All the daily rainfall indices were then calculated from the daily data set for each station for the period 1984-2014. The definition of the indices was taken from the Expert Team on Climate Change detection Indices (ETCCDI).

Methods of analysis: Long-term changes in the daily, seasonal and annual rainfall indices were computed using the nonparametric MannKendall's test and Sen's slope estimator using MAKESENSMicrosoft Excel add-in software developed by the Finnish Meteorological Institute. ${ }^{37}$ Mann Kendall test is a statistical test widely used for the analysis of trend in climatologic and in hydrologic time series. ${ }^{38-41}$ There are two advantages of using this test. First, it is a non parametric test and does not require the data to be normally distributed. Second, the test has low sensitivity to abrupt breaks due to inhomogeneous time series. Trend analysis using linear regression assumes normality and homogeneity of variance throughout the series and may be adversely affected by outliers and missing data. ${ }^{41}$
However, the nonparametric statistics are usually much less affected by the presence of outliers, data errors and missing values, and they represent a measure of monotonic dependence whether linear or not. ${ }^{37}$ Therefore, the nonparametric Mann-Kendall trend test is robust since trends in climatic series are rarely linear. ${ }^{20,41}$ The data of the selected stations were subjected to trend analysis using Mann-Kendall test. MAKESENS was used to perform two types of statistical analyses. First the presence of a monotonic increasing or decreasing trend was tested with the nonparametric Mann-Kendall test and secondly the true slope of the existing linear trend (as change per year) was estimated with the nonparametric Sen's method..$^{42}$ The Sen's method uses a linear model to estimate the slope of the trend. It is given as,

$$
f(t)=Q t+B
$$

Where $f(t)$ is the estimated rainfall amount at $t$ year;

$\mathrm{Q}$ is the slope;

$\mathrm{B}$ is a constant. 
Variability of rainfall was computed using Standardized Rainfall Anomaly (SRA) method. ${ }^{43}$ Standardized Rainfall Anomaly (SRA) was computed as the difference between the annual total of a particular year and the long term average rainfall records divided by the standard deviation of the long term data. This index is used to evaluate the inter-annual fluctuations of rainfall in the study area over the period of observation, which is given as:

$$
S R A=(P t-P m) / \sigma
$$

where: SRA is standardized rainfall anomaly;

$\mathrm{Pt}$ is annual rainfall in year $\mathrm{t}$;
Pm is long term mean annual rainfall over a period of observation;

$\sigma$ is standard deviation of annual rainfall over the period of observation.

As indicated in ${ }^{43}$ SRA is helpful to determine the level of drought severity. Accordingly the drought severity classes are extreme drought if (SRA $<-1.65)$, severe drought $(-1.65<\mathrm{SRA}<-1.28)$, moderate drought $(-1.28<$ SRA $<-0.84)$, and no drought (SRA $>-0.84)$. To assess the spatial extent of rainfall in the study area, trend time series values of each meteorological station have been interpolated by Inverse Distance Weighted (IDW) method using the Spatial Analyst tool of ArcGIS. The IDW method gives better representation for interpolation of rainfall distribution over heterogeneous topographic terrain. ${ }^{44}$

Table 2 Definitions of extreme rainfall indices selected for this study

\begin{tabular}{|c|c|c|c|c|}
\hline $\mathbf{S} / \mathbf{N}$ & Index & Index name & Definition & Unit \\
\hline I & $\mathrm{RXI}$ day & Maximum one day rainfall & Highest rainfall amount in one day & $\mathrm{mm}$ \\
\hline 2 & $\mathrm{R} \times 5$ day & Maximum five days Rainfall & Highest rainfall amount in five days & $\mathrm{mm}$ \\
\hline 3 & $\mathrm{R} 20 \mathrm{~mm}$ & Very heavy rainfall days & Count of days where rainfall $\geq 20 \mathrm{~mm}$ & Days \\
\hline 4 & SDII & Simple daily intensity index & Mean rainfall amount in wet days & $\mathrm{mm}$ day-I \\
\hline 5 & NWD & Number of wet Days & Count of wet days where rainfall $>1 \mathrm{~mm}$ & Days \\
\hline 6 & PRCPTOT & Annual total wet-day rainfall & Total rainfall in wet days (Rainfall $>$ I mm) & Days \\
\hline 7 & CDD & Consecutive dry days & Maximum length of dry spell in a year (rainfall<I mm) & Days \\
\hline 8 & CWD & Consecutive wet days & Maximum length of wet spell in a year (rainfall $\geq 1 \mathrm{~mm}$ ) & Days \\
\hline 9 & R99p & 99th percentile of daily rainfall & The 99 th percentile of daily rainfall amount & $\mathrm{mm}$ \\
\hline
\end{tabular}

\section{Results and discussion}

This study presents analyses of trends in extreme rainfall indices, which are commonly used for climate change studies, as well as their temporal and spatial patterns in south Wollo, Ethiopia. There was no previous study that has been conducted with these stations and study period (1984-2014). The study used daily rainfall records from six stations for the period 1984-2014.

\section{Rainfall variability and trends \\ Variability of annual and seasonal rainfall}

The mean annual and seasonal rainfall variability at the six stations is presented in Table 3. Rainfall is bimodal in the study area. The region receives high rainfall during summer (kiremt; main rain period) reaching up to $67 \%$. The contribution of this season for the average annual rainfall was very high across stations. The spring (belg rain from March-May) rainfall also contributes a considerable amount (17.6\%-21\%) for the annual total rainfall of stations. According to ${ }^{14}$ the rainfall during belg over parts of central Ethiopia where the study stations located was due to migratory low-pressure systems originating in the Mediterranean area and move eastward and interact with the equatorial/ tropical systems which causes the south-easterly winds from the Indian Ocean blowing towards a thermal low (cyclone) which develops over the south of Sudan during this season and produces rains in March, April and May. The mean annual rainfall of the six recording stations was $1025.6 \mathrm{~mm}$. Dessie received the highest mean annual rainfall and Haik received the lowest mean annual rainfall. The variability of annual rainfall was lowest compared to the seasonal variations (Table 3 ). But the seasonal rainfall variability was highest from Dec-Feb in which dry condition (Bega) prevails in northern Ethiopia and lowest in summer (June-August). According to ${ }^{45}$ the degree of variability of rainfall events is classified as less (20), moderate $(20<\mathrm{CV}<30)$, and high $(\mathrm{CV}>30)$.

Rainfall in South Wollo showed moderate inter-annual variability as shown by the coefficients of variations (Table 3. The spring (belg) and the winter (bega) rainfalls are found much more variable ( $>30 \%)$ than the Kiremt rainfall in which the coefficient of variation is lower than $30 \%$. Generally, the seasonal rainfall variability was higher than the annual rainfall variability. The spring rainfall was highly variable in western stations when compared to eastern stations. This finding agrees with the result of Bewket \& Conway $^{19}$ in their study that analyzed rainfall data from 12 stations in drought-prone areas of Amhara Region and Ayalew et al. ${ }^{7}$ In their study that analyzed variability of rainfall and its current trend from 10 stations of Amhara region, Ethiopia reported that spring and winter rainfalls were more variable than summer rainfall. Further the standardized rainfall anomalies (SRA) were also calculated to assess the inter-annual rainfall fluctuations at the 6 stations. The SRA showed proportion of negative anomalies ranged from $46.66 \%$ (Wereilu) to $53.33 \%$ (Ambamariam) of total number of observations during the period between 1984 and 2014 (Figure 2).The temporal analysis indicated that rainfall pattern in the study area exhibited a moderate inter-annual variability over time. 
Table 3 Mean annual and seasonal rainfall $(\mathrm{mm})$ and coefficient of variation, I984-20I4

\begin{tabular}{|c|c|c|c|c|c|c|c|c|c|c|}
\hline \multirow[t]{2}{*}{ Bimodal stations } & \multicolumn{2}{|l|}{ Annual } & \multicolumn{2}{|c|}{ Spring (MAM) } & \multicolumn{2}{|c|}{ Summer (JJA) } & \multicolumn{2}{|c|}{ Autumn (SON) } & \multicolumn{2}{|c|}{ Winter (DJF) } \\
\hline & Mean & CV (\%) & Mean & CV (\%) & Mean & CV (\%) & Mean & CV (\%) & Mean & CV (\%) \\
\hline Ambamariam & 930.35 & 14.63 & 178.6 & 51.83 & 611.56 & 24.52 & 96.59 & 43.46 & 43.34 & 66.4 \\
\hline Combolcha & 1006.6 & 15.36 & 218.56 & 42.03 & 560.91 & 29.47 & 162.46 & 39.76 & 64.67 & 78.23 \\
\hline Dessie & 1205.88 & 19.88 & 258.57 & 41.8 & 645.83 & 33.17 & 201.65 & 40.83 & 99.84 & 78.93 \\
\hline Mekaneselam & 1048.24 & 19.36 & 191.75 & 57.75 & 665.51 & 26.23 & 136.77 & 67.64 & 54.21 & 95.33 \\
\hline Wereilu & 1047.23 & 26.9 & 184.67 & 50.95 & 636.72 & 29.57 & 108.33 & 58.54 & 57.51 & 77.35 \\
\hline
\end{tabular}

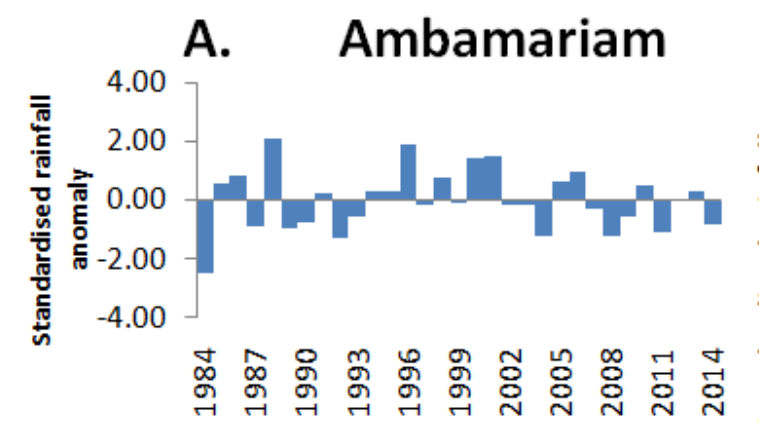

\section{B. Combolcha}

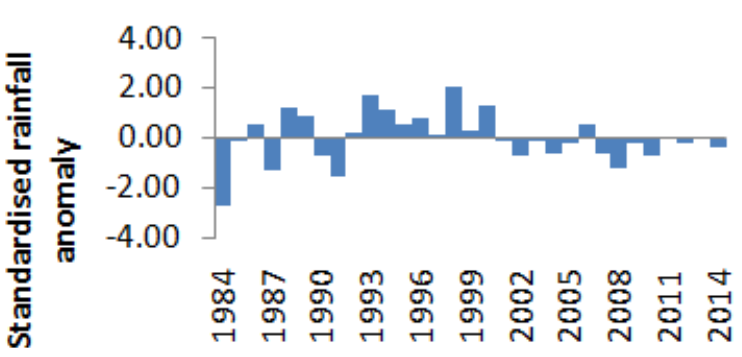

C. Dessie
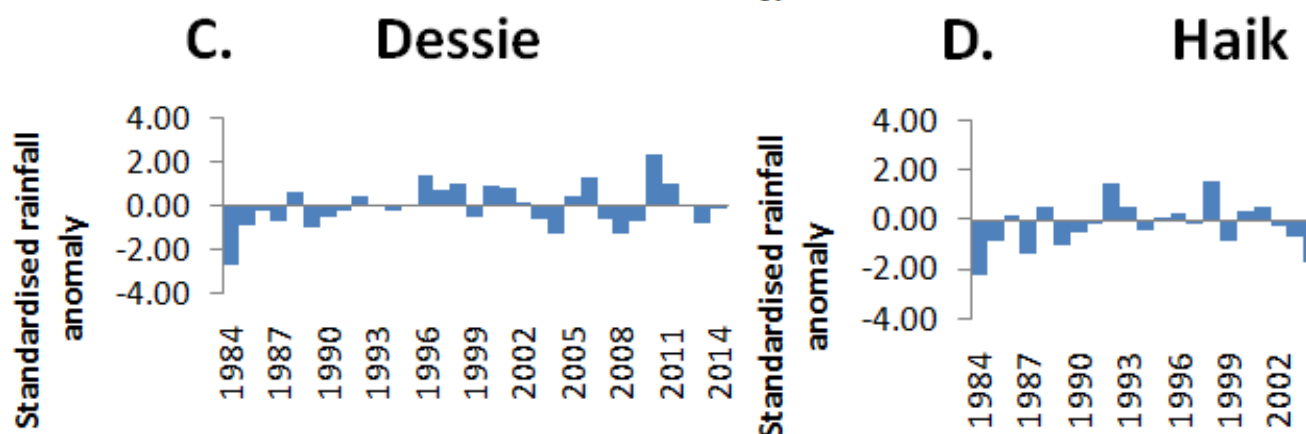

E.

Wereilu

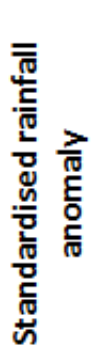

4.00

2.00

0.00

$-2.00$

$-4.00$

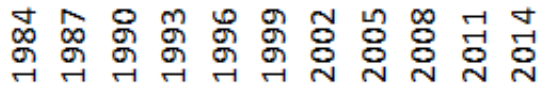

F.

Mekaneselam
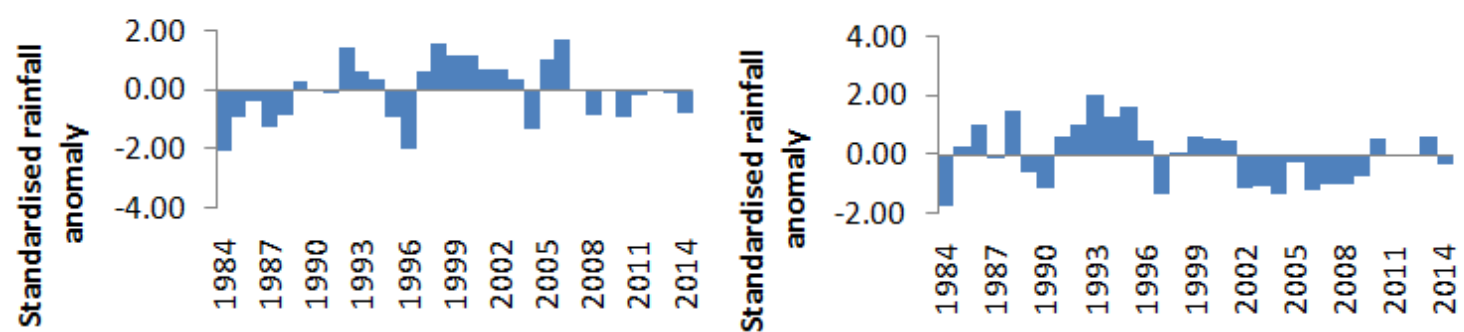

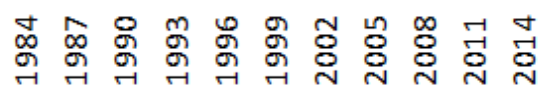

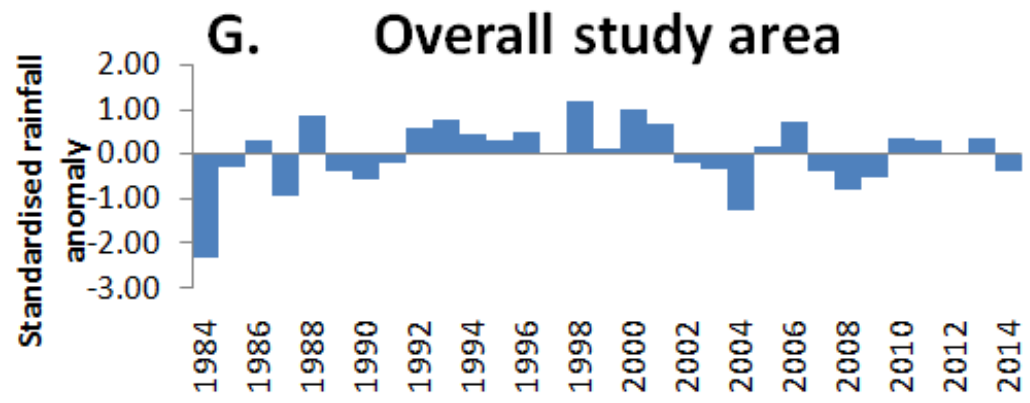

Figure 2(A-G) Standardized annual rainfall anomalies at six stations and $G$ for area-averaged rainfall for South Wollo for the period I984-20I4. 
In the second pronounced driest year 2004, the annual rainfall of all stations, except Combolcha, was more than 1.25 times the standard deviation below the long term average (1984-2014). Slight positive annual rainfall anomalies were observed in all stations in the year 1998 and 2000. Combolcha, Dessie, Haik and Mekaneselam stations noted annual rainfall of 2.02, 2.4, 2.14 and 2.06 times the standard deviation above the 1984-2014 mean rainfall during 1998, 2010, 2011 and 1993, respectively (Figure 2). The long-term areal annual rainfall from its long-term average (1984-2014) was negative during 1980s and 2000s; positive during 1990s. The negative anomalies were attributed to the strong El Niño events prevailing in east Africa (FAO 2014). This result is supported by the findings of Bewket \& Conway, ${ }^{19}$ Ayalew et al. ${ }^{7}$ Viste et al. ${ }^{22}$ Gebrehiwot $\&$ Veen $^{46}$ that reported the year 1984 was recorded for its lowest rainfall (worst drought) in the region and the recovery of rainfall over much of Ethiopia since the 1990s. Generally, the rainfall in south Wollo was characterized by irregular fluctuation of wet and dry years. The present study showed thirteen years negative deviations of areal annual rainfall from its long-term average, most of which was occurred during the 1980s and 2000s.

\section{Trends of annual and seasonal rainfall}

Trends in mean annual and seasonal rainfall at the six stations are presented in Table 4. The Mann-Kendall trend test was used to calculate the trends of mean annual rainfall totals and seasonal rainfall patterns in the study region. The Mann-Kendall test requires the time series data to be serially independent. ${ }^{47}$ The presence of a significant positive serial correlation tends to overestimate the significance of the trend. ${ }^{47,48}$ Thus, the time series data should be tested for serial correlation and should be corrected if there is any significant autocorrelation. ${ }^{47,49}$ Before the data is subjected to the Mann-Kendall trend test. In order to improve the performance of the test (MK), the most widely used procedure of the trend-free pre-whitening (TFPW) method can be applied to remove serial correlation from the time series, and hence to eliminate the effect of serial correlation on the Mann-Kendall (MK) test. ${ }^{47,48}$ In this study, we found that Ambamariam and Wereilu at annual timescale showed significant autocorrelation $(\mathrm{P}=0.59$ and 0.55$)$ respectively. TFPW method was applied to remove the autocorrelation of these two stations following the works of Petrow \& Merz ${ }^{47}$ Yue et al. ${ }^{48}$ Finally we run the Mann-Kendall test.

The MK test indicated the absence of clear trend in mean annual rainfall of studied stations. Although the mean annual rainfall showed increasing trend at Dessie, Haik and Wereilu and decreasing trends at Ambamariam, Combolcha and Mekaneselam, none of these increasing or decreasing trends was statistically significant. The mean annual areal total rainfall has shown a slight non-significant increasing trend of $4.5 \mathrm{~mm}$ per decade. There was no clear and significant trend in mean annual rainfall in the study region. This result agrees with the findings of Conway ${ }^{17}$ in northeastern Ethiopian highlands, Sileshi \& Zanke ${ }^{14}$ in central, northern, and northwestern Ethiopia, MezeHausken $^{18}$ in Northern Ethiopia and Ayalew et al. ${ }^{7}$ in Amhara region who reported the absence of significant and clear trend in the annual rainfall pattern. Seasonal trend analysis revealed that summer rainfall showed an increasing trend in all study stations but statistically significant at Dessie, Haik and Mekaneselam $(\mathrm{P}<0.05)$ (Table 4). On the contrary, the spring (Mar-May) rainfall, in all study stations, showed decreasing trends ranging from $8.55 \mathrm{~mm} /$ decade to $50.52 \mathrm{~mm} /$ decade but significant only at Mekaneselam $(\mathrm{P}<0.05)$. Generally, the two most important rainfall seasons in the region are spring and summer which showed a tendency of decreasing and increasing trends respectively Figure 3.

The results of this study agree with the findings of Bewket \& Conway, ${ }^{19}$ Rosell, ${ }^{8}$ Viste et al. ${ }^{22}$ Mengistu et al..${ }^{5}$ that reported significant declining trends in spring and increasing trends in summer rainfall. It also agrees with the findings of ${ }^{11}$ who reported the increasing trends of summer rainfall in the greater horn of Africa including Ethiopian highlands. However, it contradicts with the findings of Seleshi \& Camberlin $^{25}$ who reported the absence of significant trends in the main (summer) and short (belg) rain period in many parts of Ethiopia except the eastern, southwestern and southern parts. It also contradicts with the findings of Rosell \& Holmer ${ }^{8}$ and Sileshi \& Zanke ${ }^{14}$ who reported increasing trends of spring rainfall at Combolcha and Dessie and no significant trend in spring rainfall at Combolcha respectively. A steady decrease in the horn of Africa rains during the last 30 years (35-45\% below normal), was associated with the steady increase in sea surface temperatures (SST) of the Southern Tropical Indian Ocean (STIO) due to increasing global temperatures. ${ }^{50,51}$ Williams \& Funk ${ }^{10}$ also found that higher SSTs in the STIO have driven large increases in convection and rainfall over the STIO. The resulting increase in the amount of adiabatic energy released during rainfall has led to increased divergence of dry static energy (DSE) in the mid- and upper troposphere. During spring, this intensified outflow of mid- and upper-tropospheric DSE from the STIO has increased subsidence over northern Africa and decreased moisture transport into the great horn of Africa for at least the past 30 years. These subsequent changes in moisture transport may alter the inter-annual variability of rainfall in the region.

Table 4 Trends of annual and seasonal RF at six stations, 1984-20I4

\begin{tabular}{|c|c|c|c|c|c|c|c|c|c|c|}
\hline \multirow[b]{2}{*}{$\begin{array}{l}\text { Bimodal } \\
\text { stations }\end{array}$} & \multicolumn{2}{|l|}{ Annual } & \multicolumn{2}{|c|}{ Spring (MAM) } & \multicolumn{2}{|c|}{ Summer (JJA) } & \multicolumn{2}{|c|}{ Autumn (SON) } & \multicolumn{2}{|c|}{ Winter (DJF) } \\
\hline & $\begin{array}{l}\text { trend } \\
(\mathrm{mm} / \mathrm{IO} \\
\mathrm{yrs})\end{array}$ & $\begin{array}{l}\text { Mann- } \\
\text { kendal } \\
\text { test }\end{array}$ & $\begin{array}{l}\text { trend } \\
(\mathrm{mm} / 10 \\
\mathrm{yrs})\end{array}$ & $\begin{array}{l}\text { Mann- } \\
\text { kendal } \\
\text { test }\end{array}$ & $\begin{array}{l}\text { trend } \\
(\mathrm{mm} / 10 \\
\mathrm{yrs})\end{array}$ & $\begin{array}{l}\text { Mann- } \\
\text { kendal } \\
\text { test }\end{array}$ & $\begin{array}{l}\text { trend } \\
(\mathrm{mm} / 10 \\
\mathrm{yrs})\end{array}$ & $\begin{array}{l}\text { Mann- } \\
\text { kendal } \\
\text { test }\end{array}$ & $\begin{array}{l}\text { trend } \\
(\mathrm{mm} / 10 \\
\mathrm{yrs})\end{array}$ & $\begin{array}{l}\text { Mann- } \\
\text { kendal } \\
\text { test }\end{array}$ \\
\hline Ambamariam & -8.36 & -0.18 & -31.88 & -1.68 & 50.62 & 1.57 & $-25.95 * *$ & -2.96 & -0.5 & -1.11 \\
\hline Combolcha & -32.5 & -0.99 & -32.44 & -1.84 & 45.73 & 1.43 & -8.84 & -0.71 & $-20.47^{*}$ & -2.14 \\
\hline Dessie & 66.36 & 1.28 & -28.87 & -0.89 & $|3| .89 * *$ & 2.68 & $|2.4|$ & 1.09 & $-40.56 * *$ & -2.6 \\
\hline Haik & 57.71 & 1.61 & -8.55 & -0.61 & $71.27 * *$ & 2.68 & 13.2 & 1.14 & 57.71 & 1.61 \\
\hline Mekaneselam & -55.31 & -1.07 & $-50.52^{*}$ & -2.43 & $73.73 *$ & 2.36 & $-41.40 *$ & -2.5 & $-16.86 *$ & -2.23 \\
\hline Wereilu & 46.83 & 0.93 & -12.83 & -0.46 & 56.08 & 1.46 & 18.83 & 0.82 & $-\mid 1.31$ & -1 \\
\hline
\end{tabular}

***,**,* Significant at $0.00 \mathrm{I}, 0.0 \mathrm{I}$ and 0.05 level respectively 

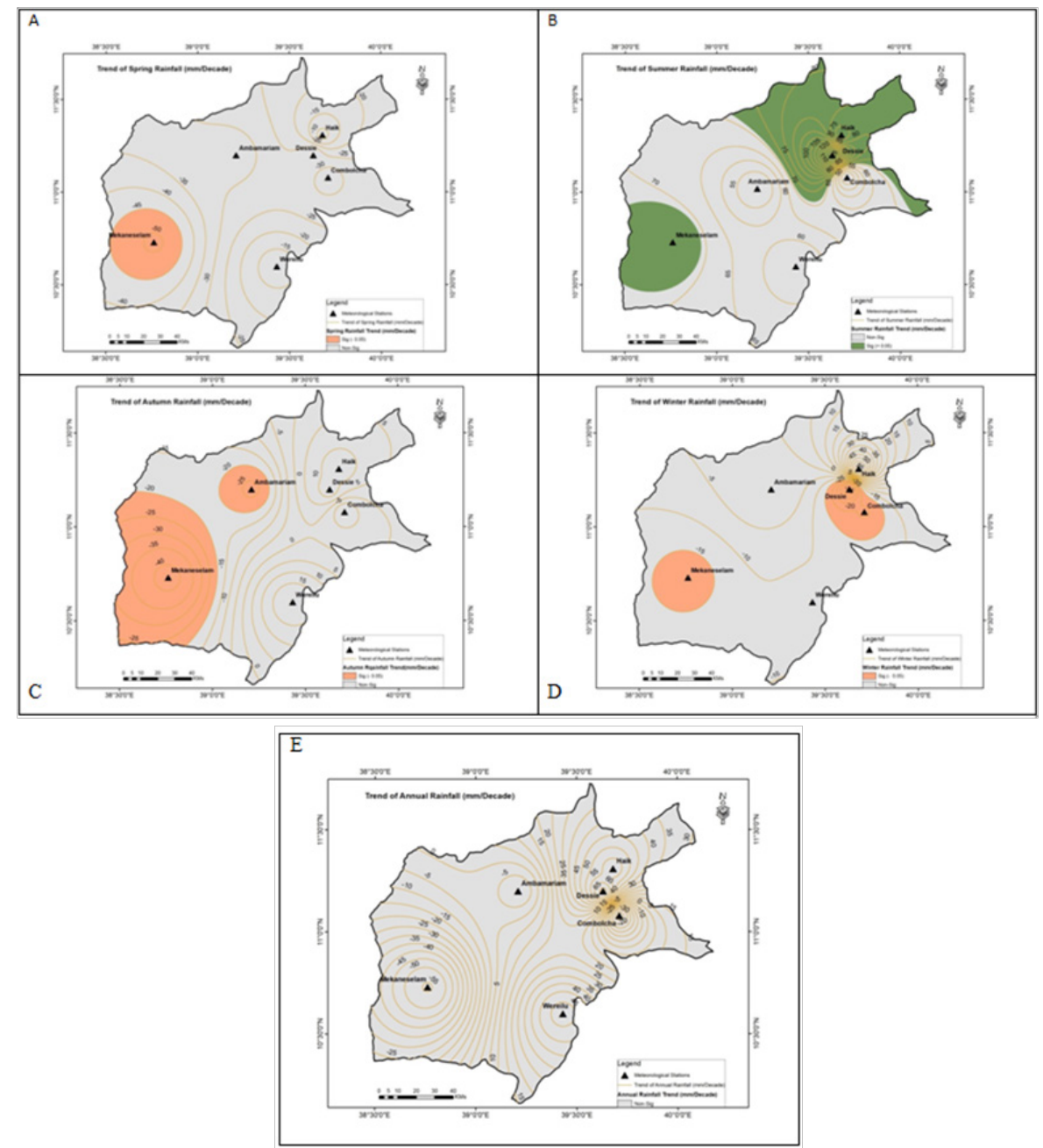

Figure 3 (A) Spatial distribution and trends of mean spring (MAM) rainfall; (B)Mean summer (JJA) rainfall; (C)Mean autumn (SON) rainfall; (D)Mean winter (DJF) rainfall; (E)Mean annual rainfall, in north east highlands of Ethiopia (I984-20I4).

\section{Variations and trends of extreme rainfall events}

Maximum one day (RX1 day) and maximum five days (RX5 days) rainfall: Table 5 presents trends of extreme rainfall indices at annual and seasonal time scales at six stations. As it is indicated, the mean annual maximum one day (RX1day) rainfall ranged from $46.51 \mathrm{~mm}$ (at Haik) to $69.02 \mathrm{~mm}$ (at Dessie). The mean annual maximum five days (RX5day) rainfall amount varied from $99.43 \mathrm{~mm}$ (at Haik) to $138.48 \mathrm{~mm}$ (at Dessie). Except significant decreasing trend in Mekaneselam, there was no clear and significant trend in the mean annual maximum one day (RX1day) rainfall. On the other hand, except Ambamariam and Mekaneselam, the mean annual maximum 5-days (RX5day) rainfall amount showed increasing tendency over other stations. However, none of them showed significant changes in statistical terms. There was no huge difference in annual maximum (RX1) and (RX5) rainfall across the studied stations.

At seasonal time scales, the trend analyses did not show systematic patterns among the recording stations for the study period. Exceptionally, the mean maximum one day (RX1day) and five day
(RX5day) rainfall amounts at Mekaneselam showed a statistically significant declining trend almost in all seasons. The five day (RX5day) rainfall amount also showed significant increasing trend in Dec-Feb rainfall at Combolcha and Dessie.

Very heavy rainfall days $(\mathrm{R} 20 \mathrm{~mm})$ and $99^{\text {th }}$ percentile of $(\mathrm{R} 99 \mathrm{p})$ daily rainfall: The annual occurrence of very heavy rainfall ( $R 20 \mathrm{~mm}$ ) event was lowest at Haik (10 days) and highest at Dessie (18 days). Likewise, the mean annual extremely wet day rainfall (R99p) amount was lowest $(27.87 \mathrm{~mm})$ at Haik and highest $(39.69 \mathrm{~mm})$ at Dessie. The annual number of days with very heavy rainfall (R20mm) showed increasing trends in four out of six stations, however, they were not statistically significant. However, the number of days with very heavy rainfall (R20mm) at Mekaneselam showed significant declining trend $(\mathrm{P}<0.05)$. The annual number of very heavy rain days did not show noticeable variation in respective seasons across all stations in the studied period (Table 5). Similarly, out of six, four stations showed increasing trends in the mean annual ninety-ninth percentile (R99p) of the daily rainfall amount but statistically significant $(\mathrm{P}<0.05)$ only at Dessie. 
Table 5 Trends in extreme rainfall events at annual and seasonal timescale

\begin{tabular}{|c|c|c|c|c|c|c|c|c|c|}
\hline Station & Timescale & $\begin{array}{l}\text { RxI day } \\
(\mathrm{mm})\end{array}$ & $\begin{array}{l}\text { trend } \\
(\mathrm{mm} / \mathrm{l} 0 \\
\text { year })\end{array}$ & $\begin{array}{l}\text { Rx5 day } \\
(\mathrm{mm})\end{array}$ & $\begin{array}{l}\text { trend } \\
(\mathrm{mm} / 10 \\
\text { year })\end{array}$ & $\begin{array}{l}\text { R20 mm } \\
\text { (No. of } \\
\text { days) }\end{array}$ & $\begin{array}{l}\text { trend (No. } \\
\text { of days/I0 } \\
\text { year) }\end{array}$ & $\begin{array}{l}\text { R99P } \\
(\mathrm{mm})\end{array}$ & $\begin{array}{l}\text { trend } \\
(\mathrm{mm} / \mathrm{l} 0 \\
\text { year) }\end{array}$ \\
\hline \multirow{5}{*}{ Ambamariam } & Annual & 52.82 & -0.13 & 117.28 & -0.19 & 11.8 & I.II & 30.94 & 1.12 \\
\hline & Spring (MAM) & 29.24 & -3.82 & 55.22 & -6.19 & 2.13 & 0 & 21.91 & -3.08 \\
\hline & Summer (JJA) & 52.1 & 0.12 & 116.4 & -0.19 & 8.9 & 1.5 & 39.8 & 0.52 \\
\hline & Autumn (SON) & 20.5 & -1.55 & 35.8 & -6.2 & 0.6 & 0 & 14.4 & -1.28 \\
\hline & Winter (DJF) & 14.52 & -1.47 & 21.93 & -3.18 & 0.23 & 0 & 9.18 & -0.37 \\
\hline \multirow{5}{*}{ Combolcha } & Annual & 56.177 & 1.18 & 116.7 & 3.21 & 14.58 & -0.59 & 33.488 & -0.29 \\
\hline & Spring (MAM) & 33.18 & -3.36 & 58.01 & -7.4 & 2.84 & $-0.91 *$ & 25.2 & $-4.4^{*}$ \\
\hline & Summer (JJA) & 54.36 & $\mathrm{I} .47$ & 115 & 3.2 & 9.46 & 1.25 & 42.06 & 2.23 \\
\hline & Autumn (SON) & 32.39 & -2.08 & 57.2 & 0 & 1.89 & 0 & 22.49 & -1.22 \\
\hline & Winter (DJF) & 18.2 & $-4.21+$ & 29.81 & $-9.65^{*}$ & 0.65 & $0+$ & 12.63 & $-4.92 * *$ \\
\hline \multirow{5}{*}{ Dessie } & Annual & 69.016 & -1.35 & 138.48 & 6.81 & 18.4 & 1.43 & 39.686 & $3.2^{*}$ \\
\hline & Spring (MAM) & 43.5 & 0.05 & 75.11 & -4.68 & 3.53 & -0.4 & 30.43 & 0.06 \\
\hline & Summer (JJA) & 59.6 & 4.48 & 129.2 & $16.86+$ & 10.73 & $2 *$ & 46.76 & $5.5+$ \\
\hline & Autumn (SON) & 39.27 & 2.09 & 72.5 & 4.77 & 2.77 & 0 & 27.19 & $3.18+$ \\
\hline & Winter (DJF) & 26.9 & -5.54 & 44.32 & $-|3.8| *$ & 1.37 & $-0.5^{*}$ & 18.93 & $-5.76^{*}$ \\
\hline \multirow{5}{*}{ Haik } & Annual & 46.51 & 0.44 & 99.43 & 4.1 & 10.27 & 1.18 & 27.87 & 0.26 \\
\hline & Spring (MAM) & 67.67 & -1.17 & 28.72 & -2 & 1.67 & 0 & 21.1 & -0.6 \\
\hline & Summer (JJA) & 42.22 & $-2.4 I$ & 94.9 & 0.5 & 6.73 & 0.67 & 34.67 & -0.03 \\
\hline & Autumn (SON) & 26.66 & 2 & 48.7 & 4.67 & $\mathrm{I} .47$ & 0 & 18.83 & 1.32 \\
\hline & Winter (DJF) & 18.54 & -2.04 & 27.86 & $-7.05+$ & 0.4 & $0 *$ & 10.28 & $-2.1+$ \\
\hline \multirow{5}{*}{ Mekaneselam } & Annual & 56.13 & $-7.77^{*}$ & 125.19 & -6.7 & 15.4 & $-3.33^{*}$ & 34.01 & $-2.4+$ \\
\hline & Spring (MAM) & 30.84 & $-8.57^{* *}$ & 58.02 & $-12.33 * *$ & 2.2 & $-1.25^{* *}$ & 22.15 & $-5.6 *$ \\
\hline & Summer (JJA) & 53.5 & -8.08 & 122.5 & -5 & II.I & 0 & 41 & $-1.7 \mid$ \\
\hline & Autumn (SON) & 25.09 & $-6.5 * *$ & 52.8 & $-16.06 *$ & 1.6 & $-0.77^{* * * *}$ & 19.1 & $-5.47 * *$ \\
\hline & Winter (DJF) & $|8.7|$ & $-\left.6.9\right|^{*}$ & 27.31 & $-12.78 * *$ & 0.53 & 0 & 10.59 & $-4.95^{* *}$ \\
\hline \multirow{5}{*}{ Wereilu } & Annual & 56.15 & 1.88 & 119.93 & 9.4 & 15.13 & 1.67 & 34.49 & $3.85+$ \\
\hline & Spring (MAM) & 31.38 & -4 & 55.02 & -5.9 & 2.4 & 0 & 24 & -2.2 \\
\hline & Summer (JJA) & 54.7 & $\mathrm{I} .84$ & 119.5 & 9.14 & 10.23 & 1.67 & 43.81 & 3.22 \\
\hline & Autumn (SON) & 30.85 & 1.74 & 58.3 & 6.71 & 2.27 & $0.67+$ & 23.62 & 2.47 \\
\hline & Winter (DJF) & 16.91 & -3 & 27.93 & -5.17 & 0.5 & 0 & 11.15 & -1.7 \\
\hline
\end{tabular}

***, **, * Significant at $0.001,0.01$ and 0.05 level respectively

At seasonal time scale, the number of days with heavy rainfall (R20mm) at Mekaneselam has shown statistically significant declining trends in March-May and September-November seasons $(\mathrm{P}<0.001)$. Significant increasing trend of $\mathrm{R} 20 \mathrm{~mm}$ was shown only at Dessie during summer (June-August) at $\mathrm{P}<0.05$. As shown in Table 5, Combolcha, Dessie and Mekaneselam stations experienced significant declining trend of $\mathrm{R} 99 \mathrm{p}$ from December-February $(\mathrm{P}<0.05)$. Generally, out of 120 rainfall extreme event indices $(\mathrm{Rx} 1$ day, Rx5 day, R20mm and R99p) at the six stations for the annual and seasonal time scales, about $36.67 \%$ of them showed increasing trends,
$51.67 \%$ decreasing trends, and $11.67 \%$ showed no trend. However, only $19.17 \%$ extreme event indices showed statistically significant trends at a few stations. Although most of the daily rainfall indices did not show statistically significant changes, there were decreasing tendencies. This has an implication for the occurrences of agricultural droughts which have a significant direct impact on smallholder farmers' livelihood who mainly depend on rainfed agriculture. The results of this study agree with the findings of past studies, $, 5,7,8,19,29$ which reported absence of regular patterns or trends in the extreme daily rainfall indices in Amhara region. 
Consecutive dry and wet days (dry and wet spells): The lengths of annual maximum number of consecutive dry days (CDD) in all stations in the study period were longer where the lowest was 56 days. On the other hand, the length of annual maximum number of consecutive wet days (CWD) was shortest (11 days) at Combolcha and longest (18 days) at Mekaneselam. Except Ambamariam, there was decreasing trends in annual maximum number of consecutive dry days (CDD) at all stations but statistically significant $(\mathrm{P}<0.05)$ at Dessie, Haik and Wereilu. Similarly, except Wereilu, the annual maximum number of consecutive wet days (CWD) showed increasing trends in all stations, but statistically significant at Ambamariam and Mekaneselam and Dessie (Table 6). At seasonal time scale, there were decreasing tendencies in the annual maximum number of consecutive dry days (CDD). Over $70 \%$ of the seasons in six stations showed decreasing trends of annual maximum number of consecutive dry days (CDD). Even though there were differences in seasons, remarkable significant decreasing trends $(\mathrm{P}<0.05)$ of $\mathrm{CDD}$ were found at all stations except Ambamariam. On the other hand, the annual maximum number of consecutive wet days (CWD) showed no trend in short rain period (March-May) except a decreasing tendency at Ambamariam and Combolcha. In contrast, there were increasing trends of CWD in the main rain period (June-August) in all stations except Wereilu.

Trends in number of wet days, total wet day rainfall and daily rainfall intensity (NWD,PRCPTOT and SDII): Table 6 shows spatial variations and trends in NWD, PRCPTOT and SDII. Variations and trends in the number of wet days (NWD), annual total wet day rainfall (PRCPTOT) and simple daily rainfall intensity index (SDII) showed no significant spatial variations among the six stations. The
NWD ranged from 91days at Ambamariam to 105days at Haik; PRCPTOT ranged from $905 \mathrm{~mm}$ at Haik to $1199 \mathrm{~mm}$ at Dessie and The SDII varied from $8.75 \mathrm{~mm}$ at Haik to $12 \mathrm{~mm}$ at Dessie. Trends in NWD, PRCPTOT and SDII were not significant at most of the stations. The NWD showed increasing tendency in Dessie, Haik and Mekaneselam though it was significant only at Mekaneselam $(\mathrm{P}<0.01)$. Despite fluctuating tendencies of PRCPTOT, there was no any significant trend. The SDII also showed significant $(\mathrm{P}<0.01)$ decreasing trend only at Mekaneselam.

At seasonal time scale, significant changes were observed only in the short rain period (March-May) and main rain period (June-August). Although it was not significant in statistical terms, all stations, except Haik, showed decreasing trend for the NWD during the short rain period (March-May) indicating tendencies for increasing of NDD. Inversely, all stations except Wereilu showed significant increasing trend of NWD during the main rain period (June-August). Over $62 \%$ of the seasons showed a declining trend in the annual total wet day rainfall (PRCPTOT). All of the stations experienced decreasing trends in PRCPTOT during the short rain period (March-May), of which Mekaneselam was statistically significant $(\mathrm{P}<0.05)$. Conversely, all of the stations showed increasing trends in PRCPTOT during the main rain period (June-August) but only significant at Dessie $(\mathrm{P}<0.01)$ and Mekaneselam $(\mathrm{P}<0.05)$. Over $66 \%$ of the seasons, showed a declining trend in SDII, however, significant at Combolcha for the short rain period (March-May) and Mekaneselam for all seasons. The decreasing trends of SDII at Mekaneselam in all seasons indicate that the agricultural production was at risk.

Table 6 Trends in extreme rainfall events at annual and seasonal timescale at six stations from 1984-2014

\begin{tabular}{|c|c|c|c|c|c|c|c|c|c|c|c|}
\hline Station & Timescale & $\begin{array}{l}\text { CDD } \\
\text { (No. of } \\
\text { days) }\end{array}$ & $\begin{array}{l}\begin{array}{l}\text { trend } \\
\text { (no. of }\end{array} \\
\text { days } \\
110 \\
\text { year) }\end{array}$ & $\begin{array}{l}\text { CWD } \\
\text { (No. of } \\
\text { days) }\end{array}$ & $\begin{array}{l}\text { trend } \\
\text { (no. of } \\
\text { days } \\
110 \\
\text { year) }\end{array}$ & $\begin{array}{l}\text { NWD } \\
\text { (No. of } \\
\text { days) }\end{array}$ & $\begin{array}{l}\text { trend } \\
\text { (no. of } \\
\text { days / I0 } \\
\text { year) }\end{array}$ & $\begin{array}{l}\text { PRCPTOT } \\
(\mathrm{mm})\end{array}$ & $\begin{array}{l}\text { trend } \\
(\mathrm{mm} / 10 \\
\text { year })\end{array}$ & $\begin{array}{l}\text { SDII } \\
(\mathrm{mm})\end{array}$ & $\begin{array}{l}\text { trend } \\
(\mathrm{mm} / 10 \\
\text { year })\end{array}$ \\
\hline \multirow{5}{*}{ Ambamariam } & Annual & 59.67 & 0 & 14.8 & $3.81 * *$ & 90.67 & -1.67 & 923.45 & -10.21 & 10.26 & 0.32 \\
\hline & Spring (MAM) & 22.47 & 0.63 & 4.33 & -0.48 & 19.67 & -2.22 & 177.2 & -31.77 & 8.8 & -0.71 \\
\hline & Summer (JJA) & 19.6 & 1.58 & 14.7 & $4.00 * *$ & 49.6 & $4.17 * *$ & 608.9 & 51.96 & 12.3 & 0.1 \\
\hline & Autumn (SON) & 43.6 & -2 & 3.9 & $-0.5^{*}$ & 14.7 & $-0.269 * *$ & 94.6 & $-25.7 I^{*}$ & 6.4 & -0.74 \\
\hline & Winter (DJF) & 42.9 & 2.86 & 2.27 & 0 & 6.77 & -1.25 & 42.77 & -5.25 & 6.47 & 0.32 \\
\hline \multirow{5}{*}{ Combolcha } & Annual & 55.32 & -0.63 & 10.94 & 0.8 & 96.74 & 0 & 994.35 & -31.75 & 10.28 & 0.01 \\
\hline & Spring (MAM) & 20 & 0.42 & 4.71 & -0.42 & 22.94 & -0.67 & 215.13 & -34.06 & 9.23 & $-1.15^{*}$ \\
\hline & Summer (JJA) & 19.4 & 0 & 10.69 & 1.36 & 46.39 & $4 *$ & 569.5 & 46.73 & 12.24 & 0.22 \\
\hline & Autumn (SON) & 35.6 & -3.53 & 4.39 & 0 & 19.77 & 0 & 166.9 & -9 & 57.19 & 0 \\
\hline & Winter (DJF) & 40.08 & 0 & 3.35 & 0 & 9.69 & -2 & 63.26 & $-19.33 *$ & 6.41 & -1.2 \\
\hline \multirow{5}{*}{ Dessie } & Annual & 56.266 & $-7.5^{*}$ & 11.8 & $1.67^{*}$ & 100.066 & 3.33 & 1199.25 & 65.38 & 11.945 & 0.2 \\
\hline & Spring (MAM) & 19 & -1.05 & 5.63 & 0 & 24.87 & -0.48 & 256.54 & -28.53 & 10.34 & -0.68 \\
\hline & Summer (JJA) & 19.7 & -0.5 & $1 \mathrm{I} .47$ & $2 * *$ & 46.2 & $5.83 * * *$ & 643.5 & $129.22 * *$ & 13.7 & 1.19 \\
\hline & Autumn (SON) & 39.2 & $-7.86 * *$ & 4.6 & 0.43 & 19.2 & 1.9 & 200.4 & 11.72 & 10.54 & -0.4 \\
\hline & Winter (DJF) & 41.57 & -3.33 & 3.2 & $-0.63 *$ & 9.8 & $-2.5^{*}$ & 98.83 & $-40.89 * *$ & 9.31 & -1.48 \\
\hline
\end{tabular}


Table Continued.

\begin{tabular}{|c|c|c|c|c|c|c|c|c|c|c|c|}
\hline Station & Timescale & $\begin{array}{l}\text { CDD } \\
\text { (No. of } \\
\text { days) }\end{array}$ & $\begin{array}{l}\text { trend } \\
\text { (no. of } \\
\text { days } \\
110 \\
\text { year) }\end{array}$ & $\begin{array}{l}\text { CWD } \\
\text { (No. of } \\
\text { days) }\end{array}$ & $\begin{array}{l}\text { trend } \\
\text { (no. of } \\
\text { days } \\
110 \\
\text { year) }\end{array}$ & $\begin{array}{l}\text { NWD } \\
\text { (No. of } \\
\text { days) }\end{array}$ & $\begin{array}{l}\text { trend } \\
\text { (no. of } \\
\text { days / } 10 \\
\text { year) }\end{array}$ & $\begin{array}{l}\text { PRCPTOT } \\
(\mathrm{mm})\end{array}$ & $\begin{array}{l}\text { trend } \\
(\mathrm{mm} / \mathrm{l} 0 \\
\text { year })\end{array}$ & $\begin{array}{l}\text { SDII } \\
(\mathrm{mm})\end{array}$ & $\begin{array}{l}\text { trend } \\
\text { ( } \mathrm{mm} / 10 \\
\text { year) }\end{array}$ \\
\hline \multirow{5}{*}{ Haik } & Annual & 57.67 & $-10 *$ & 16.1 & 1.79 & 104.63 & 4.55 & 904.98 & 56 & 8.75 & -0.04 \\
\hline & Spring (MAM) & 20 & -1.36 & 4.53 & 0 & 23.1 & 0.48 & 175.56 & -10.14 & 10.34 & -0.46 \\
\hline & Summer (JJA) & 13.7 & -1.2 & 15.83 & 2 & 55.37 & $5^{*}$ & 521.2 & 58.38 & 9.89 & 0.16 \\
\hline & Autumn (SON) & 36.08 & -7.06 & 4.9 & 0.56 & 18.67 & 1.82 & | 39.7 & 13 & 7.56 & -0.25 \\
\hline & Winter (DJF) & 49.93 & $-6^{*}$ & 3 & 0 & 7.5 & -1 & 51.21 & -9.12 & 6.77 & -0.62 \\
\hline \multirow{5}{*}{ Mekaneselam } & Annual & 64.63 & -3.08 & 17.63 & $5.5 * * *$ & 92.9 & $7.14^{* *}$ & 1042.92 & -60 & 11.39 & $-1.49 * *$ \\
\hline & Spring (MAM) & 21.83 & 1.25 & 4.83 & 0 & 21.57 & -1.67 & 190.38 & $-50.68^{*}$ & 8.85 & $-2.01 * *$ \\
\hline & Summer (JJA) & 12.3 & $-4.35^{*}$ & 17 & $6.67 * * *$ & 49.3 & $10 * * *$ & 663.7 & $70.67 *$ & 13.9 & $1.9 *$ \\
\hline & Autumn (SON) & 43.6 & $-5.79 *$ & 4.7 & 0 & 15.9 & -1.25 & 135.2 & $-43.5^{*}$ & 8.1 & $-1.93 *$ \\
\hline & Winter (DJF) & 55.23 & 1.33 & 2.2 & 0 & 6.1 & -1.11 & 53.63 & $-17.45^{*}$ & 8.45 & $-3.15^{* *}$ \\
\hline \multirow{5}{*}{ Wereilu } & Annual & 63.1 & $-13.08 * *$ & 13.9 & -1.43 & 93.83 & -1.11 & 1041.3 & 52.88 & 11.06 & 0.57 \\
\hline & Spring (MAM) & 22 & -1.11 & 5.3 & 0 & 20.57 & -0.77 & 183.15 & -12.8 & 8.59 & -0.4 \\
\hline & Summer (JJA) & 19.9 & -2.67 & 13.7 & -1.82 & 47.77 & 0 & 634.7 & 57.25 & 13.29 & 0.93 \\
\hline & Autumn (SON) & 41.9 & $-10 * *$ & 4.33 & 0 & 18.23 & 2.35 & 183.6 & 40.5 & 9.55 & 0.88 \\
\hline & Winter (DJF) & 46.03 & -6.32 & 3.1 & 0 & 8.37 & $-|| 1$. & 56.44 & -12.1 & 6.49 & -0.89 \\
\hline
\end{tabular}

$* * *, * *, *$ Significant at $0.001,0.01$ and 0.05 level respectively

\section{Conclusion and policy implication}

This study examined the variability and trends of extreme rainfall events in south Wollo using six stations at annual and seasonal time scales in the period of 1984-2014. Based on $\mathrm{WMO}^{36}$ guideline, nine rainfall and ten temperature extreme event indices were analyzed using the daily rainfall data. Mann-Kendall's trend test and Sen's slope estimator were used to determine the statistical significance and magnitude of the changes in the extreme events, respectively. From the findings the following conclusions were drawn.

a. The study found that there was moderate inter-annual rainfall variability across the studied stations. However, it was lowest during summer season.

b. Insignificant declining tendencies of spring (belg) rainfall in all studied stations and significant increasing trends of summer (kiremt) rainfall were observed in north eastern and western parts of the study area.

c. There were no systematic patterns in the trends and spatial variations of extreme rainfall events across the studied stations. The patterns were mixed with fewer significant trends. However, significant decreasing and increasing trends of annual maximum number of consecutive dry days (CDD) and wet days (CWD) respectively were observed in most of the study stations. Number of wet days (NWD) in summer showed significant increasing trend in almost all stations. The summer total wet days rainfall (PRCPTOT) showed raising trend in all stations, however, significant at Dessie and Mekaneselam.

Generally small-holder farmers do not have any guarantee to entirely adapt to the increasingly prevailing drier or wet conditions. Rainfall was unpredictable and highly subjected to high variability. There was an urgent need to establish an effective adaptation strategy in rainfed highland cropping systems. Government organizations together with other stakeholders should engage in adapting/adopting efficient strategies in order to minimize the negative impact of climate change in the study region. As there are various small streams, constructing small scale irrigation schemes will be very important for crop production especially when the belg rain fails/declines. In order to effectively use the short and variable rainfall, providing early maturing crop varieties is recommended. Since the study area is highly degraded, watershed management practices should also be consolidated. Improving farmers' awareness to accept modern technologies of crop production and livestock rearing are also other recommendations to be practiced by various stakeholders in the study region.

\section{Acknowledgement}

None.

\section{Conflict of interest}

The authors declare that there is no conflict of interest

\section{References}

1. IPCC. Managing the risks of extreme events and disasters to advance climate change adaptation. In: Field CB, et al. Editors. A Special Report of Working Groups I and II of the Intergovernmental Panel on Climate Change. Cambridge, NY, USA: Cambridge University Press; 2012:1-594. 
2. IPCC. Summary for policymakers. In: Field CB, et al. Editors. Climate Change 2014: Impacts, Adaptation, and Vulnerability. Part A: Global and Sectoral Aspects. Contribution of Working Group II to the Fifth Assessment Report of the Intergovernmental Panel on Climate Change. Cambridge, UK \& NY, USA: Cambridge University Press; 2014:1-34.

3. IPCC. Climate Change 2013: The Physical Science Basis. Contribution of Working Group I to the Fifth Assessment Report of the Intergovernmental Panel on Climate Change. In: Stocker F, et al. Editors. New York: Cambridge University Press; 2013. 1535 p.

4. Niang I, Ruppel OC, Abdrabo MA. Et al. Africa. In: Climate Change 2014: Impacts, Adaptation, and Vulnerability. Part B: Regional Aspects. Contribution of WGII to IPCC AR5. In: Barros V, et al. Cambridge, UK \& NY, USA: Cambridge University Press; 2014:1199-1265.

5. Mengistu D, Bewket W, Lal R. Recent spatiotemporal temperature and rainfall variability and trends over the Upper Blue Nile River Basin, Ethiopia. Int J Climatol. 2014;34(7):2278-2292.

6. Hulme M, Osborn T, Johns T. Rainfall sensitivity to global warming: comparison of observations with HADCM2 simulations. Geophys Res Lett. 1998;25:3379-3382.

7. Ayalew D, Tesfaye K, Mamo G, et al. Variability of rainfall and its current trend in Amhara Region, Ethiopia. Afr J Agri Res. 2012;7(10):1475-1486.

8. Rosell S, Holmer B. Rainfall change and its implications for Spring harvest in South Wollo, Ethiopia. Geogr Ann. 2007;89(4):287-299.

9. Hession S, Moore N. A spatial regression analysis of the influence of topography on monthly rainfall in East Africa. International Journal of Climatology. 2011;31(10):1440-1456.

10. Williams AP, Funk C. A westward extension of the warm pool leads to a westward extension of the Walker circulation, drying eastern Africa. Climate Dynamics. 2011;37(11-12):2417-2435.

11. Funk C, Dettinger MD, Michaelsen JC, et al. Warming of the Indian Ocean threatens eastern and southern African food security but could be mitigated by agricultural development. Proceedings of the National Academy of Sciences of the United States of America. 2008;105(32):11081-11086.

12. Lyon B, DeWitt. A recent and abrupt decline in the East African long rains. Geophysical Research Letters. 2012;39(2):L02702.

13. Osman M, Sauerborn P. A preliminary assessment of characteristics and long-term variability of rainfall in Ethiopia basis for sustainable land use and resource management. Paper Presented at Conference on International Agricultural Research For Development. Witzenhausen, Germany. 2002;9-11.

14. Seleshi Y, Zanke U. Recent changes in rainfall and rainy days in Ethiopia. Int J Climatol. 2004;24(8):973-983.

15. Cheung WH, Senay GB, Singh A. Trends and spatial distribution of annual and seasonal rainfall in Ethiopia. Int J Climatol. 2008;28:1723-1734.

16. Verdin J, Funk C, Senay G, et al. Climate Science and famine early warning. Philos Trans R Soc. 2005;360:2155-2168.

17. Conway D. The climate and hydrology of the Upper Blue Nile. Geogr J. 2000;166(1):49-62.

18. Meze-Hausken E. Contrasting climate variability and meteorological drought with perceived drought and climate change in northern Ethiopia. Clim Res. 2004;27(1):19-31.

19. Bewket W, Conway D. A Note on the temporal and spatial variability of rainfall in the drought-prone Amhara Region of Ethiopia. Int J Climatol. 2007;27(11):1467-1477.

20. Degefu A, Bewket W. Variability and trends in rainfall amount and extreme event indices in the Omo-Gibe River Basin, Ethiopia. Reg Environ Change. 2013.
21. Jury MR, Funk C. Climatic trends over Ethiopia: regional signals and drivers. Int J Climatol. 2012;33(8):1924-1935.

22. Viste E, Korecha D, Sorteberg A. Recent drought and precipitation tendencies in Ethiopia. Theor Appl Climatol. 2013;112(3-4):535-551.

23. FEWS NET. A Climate Trend Analysis of Ethiopia. United states Geological survey. 2012;1-6.

24. Easterling DR, Evans JL, Groisman PY, et al. Observed variability and trends in extreme climate events: a brief review. Bull Amer Meteor Soc. 2006;81:417-425.

25. Seleshi Y, Camberlin P. Recent changes in dry spell and extreme rainfall events in Ethiopia. Theor Appl Climatol. 2006;83(1-4):181-191.

26. Kebede G, Bewket W. Variations in rainfall and extreme event indices in the wettest part of Ethiopia. SINET Ethiop J Sci. 2009;32(2):129-140.

27. Endalew GJ. Changes in the frequency and intensity of extremes over Northeast Africa. WR: Scientific report; 2007. 2 p.

28. Mc Sweeney C, New M, Lizcano G. UNDP climate change profile for Ethiopia. 2010.

29. Taye M, Zewdu F. Spatio-temporal Variability and Trend of Rainfall and Temperature in Western Amhara, Ethiopia: a GIS approach. Glo Adv Res J Geogr Reg Plann. 2012;1(4):65-82.

30. Hadgu G, Tesfaye K, Mamo G, et al.Trend and variability of rainfall in Tigray, Northern Ethiopia: Analysis of meteorological data and farmers' perception. Academia Journal of Agricultural Research . 2013;1(6):088100.

31. Coltorti M, Dramis F, Ollier CD. Plantation surfaces in northern Ethiopia. Geomorphology. 2007;89(3-4):287-296.

32. Bo FED. Bureau of Finance and Economic Development, 2004. Bahir Dar, Ethiopia: Development Indicators of Amhara Region; 2004.

33. Peter D Little, Priscilla Stone, Tewodaj Mogues, et al. Moving in Place: Drought and Poverty Dynamics in South Wollo, Ethiopia. Journal of Development Studies. 2006;42(2):200-225.

34. Mzirai OB, Tumbo SD, Bwana T, et al. Evaluation of Simulators of Synthetic Missing Climate Data Required for Agro-hydrological Modelling and Water Management Planning: The case of the PARCHEDTHIRST and Marksim Models. International Water Management Institute; 2005 .

35. Ngongondo C, Chong Y, Lottschalk L, Alemaw B. Evaluation of spatial and temporal characteristics of rainfall in Malawi: a case of data scarce region. Theor Appl Climatol. 2011;106(1-2):79-93.

36. WMO (World Meteorological Organization). Guidelines on: analysis of extremes in a changing climate in support of informed decisions for adaptation. Climate Data and Monitoring WCDMP-No. 72. 2009;1-55.

37. Salmi T, Ma"a"tta" A, Anttila $\mathrm{P}$, et al. Detecting trends of annual values of atmospheric pollutants by the Mann-Kendall test and Sen's slope estimates - the excel template application MAKESENS. Air Quality No 31, Finnish Meteorological Institute, Air Quality Research, Helsinki, Finland. 2002.

38. Mavromatis T, Stathis D. Response of the Water Balance in Greece to Temperature and Precipitation Trends. Theoretical and Applied Climatology. 2011;104(1-2):13-24.

39. Shahid S. Rainfall variability and the trends of wet and dry periods in Bangladesh. Int J Climatol. 2009;30(15):2299-2313.

40. Hamed K. Trend detection in hydrologic data: the Mann- Kendall trend test under the scaling hypothesis. J Hydrol. 2018;349(3):350-363.

41. De Luis M, Raventos J, Gonzalez-Hidalgo JC, et al. Spatial analysis of rainfall trends in the region of Valencia (East Spain). Int J Climatol. 2000;20(12):1451-1469. 
42. Gilbert RO. Statistical methods for environmental pollution monitoring Van NostrandReinhold; 1987:1-334.

43. Agnew CT, Chappel. Drought in the Sahel. GeoJournal. 1999;48(4):299311.

44. Gebrehiwot T, Van Der Veen A, Maathuis B. Spatial and temporal assessment of drought in the Northern highlands of Ethiopia. Int J Appl Earth Obs Geoinf. 2011;13(3):309-321.

45. Hare W. Assessment of Knowledge on Impacts of Climate Change, Contribution to the Specification of Art, 2 of the UNFCCC. WBGU. $2003 ; 106$.

46. Gebrehiwot T, Van der Veen. Assessing the evidence of climate variability in the northern part of Ethiopia. Journal of Development and Agricultural Economics. 2013;5(3):104-119.
47. Petrow Th, Merz B. Trends in flood magnitude, frequency and seasonality in Germany in the period 1951-2002. Journal of Hydrology. 2009;371(14):129-141.

48. Yue S, Pilon P, Cavadias G. Power of the Mann-Kendall and spearman's rho tests for detecting monotonic trends in hydrological series. Journal of Hydrology. 2002;259(1-4):254-271.

49. Burn DH, Sharif M, Zhang K. Detection of trends in hydrological extremes for Canadian watersheds. Hydrological Processes. 2010;24(13):17811790

50. Doreen Stabinsky. South-North Development Monitor (SUNS, No. 7187, 11 July 2011). New York: Third World Network; 2012.

51. Tesso G, Emana B, Ketema M. Analysis of vulnerability and resilience to climate change induced shocks in North Shewa, Ethiopia. Agricultural Sciences. 2012;3(6):871-888. 